\title{
Extrachromosomal DNAs of Rice Yellow Dwarf and Sugarcane White Leaf Phytoplasmas
}

\author{
Kazuo NAKASHIMA* and Takaharu HAYASHI*
}

\begin{abstract}
Rice yellow dwarf (RYD) and sugarcane white leaf (SCWL) phytoplasmas have extrachromosomal DNAs. We isolated, by sucrose density gradient centrifugation, small DNA molecules from RYD phytopiasma, which hybridized with a cloned extrachromosomal DNA fragment of the RYD phytoplasma. The isolated molecules occurred in both circular and linear forms, and their size was estimated to be about $3.8 \mathrm{~kb}$. Inverse PCR method showed that the extrachromosomal DNA of SCWL phytoplasma, which was about $2.7 \mathrm{~kb}$, has a circular form in planta. HindIII-digests of extrachromosomal DNAs of both RYD phytoplasma and HindIII or EcoRI-digests of extrachromosomal DNAs of SCWL phytoplasma showed polymorphism among isolates collected within a single field. Hybridization tests indicated that extrachromosomá! DNAs of RYD and SCWL phytoplasmas shared a considerable nucleotide sequence homology, but little homology with those of sesame phyllody phytoplasma and aster yellowstype phytoplasmas.
\end{abstract}

(Received March 2, 1995; Accepted June 15, 1995)

Key words : rice yellow dwarf, sugarcane white leaf, phytoplasma, extrachromosomal DNA.

\section{INTRODUCTION}

More than 300 diseases affecting more than 200 genera of plants have been shown to be caused by phytoplasmas (mycoplasma-like organisms [MLOs]) worldwide $^{10}$. In East and Southeast Asia, there are several phytoplasma diseases in gramineous plants, such as rice yellow dwarf (RYD) and sugarcane white leaf (SCWL), which are characterized by leaf chlorosis and proliferation of tillers ${ }^{10,15}$. The RYD phytoplasma, transmitted by green rice leafhoppers, Nephotettix cincticeps, $N$. virescens, and $N$. nigropictus, is prevalent in most rice-growing countries in Asia ${ }^{19}$. The SCWL phytoplasma, transmitted by the leafhopper Matsumuratettix hiroglyphicus causes severe losses in Thailand ${ }^{21}$. We reported that phytoplasma of a RYD isolate collected at Otawara, Tochigi, Japan (RYD-To) harbored extrachromosomal DNAs, of which random fragments were cloned in Escherichia coli $^{13)}$. DNAs hybridizing with DNA probes derived from the extrachromosomal DNAs are ubiquitous in RYD phytoplasma isolates from various locations in Japan, Thailand, and Philippines ${ }^{14)}$. Extrachromosomal DNA was also found in a Thai isolate of the SCWL phytoplasma $^{6,122}$.

Existence of plasmids or extrachromosomal DNAs has been reported in several phytoplasmas and other mollicutes ${ }^{2-5,7-9,18,23)}$. Information on physical or biologi- cal properties of extrachromosomal DNAs of phytoplasmas are in insufficient for understanding their role at the molecular level. In the present study, we demonstrate that purified extrachromosomal DNA of RYD-To phytoplasma is circular and can be differentiated by Southern hybridization from extrachromosomal DNAs of RYD phytoplasma isolates from several other locations in Japan, Thailand and Philippines. We also investigated the conformation and variability of extrachromosomal DNA of an isolate of SCWL phytoplasma from Khon Kaen, Thailand. In the light of this information, relatedness of extrachromosomal DNAs in major phytoplasmas in Asia is discussed.

\section{MATERIALS AND METHODS}

Sources of phytoplasmas. In addition to RYDTo, five RYD isolates, RYD-T-N, RYD-T-Ya, RYD-T-K, RYD-T-U, RYD-T-Yu were collected at Nishinasuno, Yaita, Kamikawachi, Ujiie, and Yuzukami in Tochigi Prefecture, respectively ${ }^{14)}$. RYD-N and RYD-K were provided by the Nagano Plant Protection Office and the Kagoshima Agriculture Experiment Station, respectively. Philippine isolates of RYD phytoplasma (RYD-Ph) and rice orange leaf (ROL) phytoplasma were provided by the International Rice Research Institute (IRRI), the Philippines, and a Thai line (RYD-Th) by the Department of Agriculture, Thailand. The RYD-To and RYD-

\footnotetext{
* Biological Resources Division, Japan International Research Center for Agricultural Sciences (JIRCAS), Tsukuba 305, Japan 国際農林水産業研究センター生物資源部
} 
Th isolates were maintained in rice (Oryza sativa) plants with successive inoculation by $N$. cincticeps or $N$. virescens. Several isolates of RYD were also collected at Yuzukami, Tochigi, Japan. Khon Kaen isolates of sugarcane (Saccharum officinarum) white leaf (SCWL), Brachiaria (Brachiaria sp.) white leaf (BraWL), Dactyloctenium (Dactyloctenium aegypcium) white leaf (DacWL), Bermudagrass (Cynodon dactylon) white leaf (BGWL), and sesame (Sesamum indicum) phyllody (SP) were collected at Khon Kaen, Thailand. Plant materials infected with onion (Allium cepa) yellows (OY) phytoplasma and gentian (Gentiana sp.) witches' broom (GWB) phytoplasma were provided by the National Agriculture Research Center, Tsukuba, Japan ${ }^{12,14}$. Paulownia (Paulownia sp.) witches' broom was collected in Tsukuba, Japan. Association of phytoplasmas with these collections was confirmed by electron microscopy, insect transmission test, or polymerase chain reaction amplification for $16 \mathrm{~S}$ rDNA $^{16)}$. DNA from periwinkle (Catharanthus roseus) plants with the western strain of aster yellows (AY) phytoplasma was given by Dr. B.C. Kirkpatrick, the University of California, Davis, California, USA.

DNA probes. Extrachromosomal DNA fragments R 32 and R 72 of RYD-To phytoplasma ${ }^{14)}$, extrachromosomal DNA fragment S 1 of SCWL phytoplasma ${ }^{12)}$, extrachromosomal DNA fragments SP 49 and SP 51 of SP phytoplasma were amplified from plasmids by $\mathrm{PCR}^{14)}$. Extrachromosomal DNA fragment PAY 45 of a severe strain of aster yellows phytoplasma was supplied by University of California, Davis, USA. DNA fragments of extrachromosomal DNAs were labeled with horseradish peroxidase using the Amersham ECL system according to the instructions of the manufacturer.

Separation of extrachromosomal DNAs. After purification of DNA of RYD-To phytoplasma from infected rice plants ${ }^{13)}$, we separated low-molecular-weight DNAs as follows. The phytoplasma DNA was layered onto a $10-40 \%$ sucrose density gradient containing $1 \mathrm{M}$ $\mathrm{NaCl}, 20 \mathrm{mM}$ Tris- $\mathrm{HCl}$ (pH 7.9), $10 \mathrm{mM}$ EDTA and centrifuged at $188,000 \times g$ for $16 \mathrm{hr}$ at $20^{\circ} \mathrm{C}$. DNA fragments separated in the gradient were fractionated $(0.5$ $\mathrm{ml}$ each) from the bottom of the centrifuge tubes. DNAs of each fraction were electrophoresed in a $0.7 \%$ agarose gel using TBE buffer ${ }^{22)}$. After the electrophoresis, DNAs were transferred from the gel to a sheet of nylon membrane (Hybond N; Amersham) and hybridized with chromosomal DNA probe R 9 and then with extrachromosomal DNA probe $\mathrm{R} 72^{14)}$. It is possible to hybridize the same membrane with several succesive probes without much interference with the other probes.

Electron microscopy. We unfolded the isolated DNA fractions which hybridized with the extrachromosomal DNA probe onto a cytochrome $c$ monolayer for electron microscopy. Samples were prepared by mixing $20 \mu 1$ DNA $(2 \mu \mathrm{g} / \mathrm{ml})$ in $0.5 \mathrm{M}$ ammonium acetate- $1 \mathrm{mM}$ EDTA with $5 \mu 1$ cytochrome $c(1 \mathrm{mg} / \mathrm{ml})$ in $0.1 \mathrm{M}$ Tris$\mathrm{HCl}$ (pH 8.5), $10 \mathrm{mM}$ EDTA. DNA spread onto a cyto- chrome $c$ monolayer was mounted on grids coated with a collodion film and stained with $5 \times 10^{-4} \mathrm{M}$ uranyl acetate in ethanolic $\mathrm{HCl}$. Thereafter the DNA was rotary-shadowed with $\mathrm{Pt} / \mathrm{Pd}$.

Southern hybridization. Undigested or HindIIIdigested DNA specimens extracted from healthy or phytoplasma-infected plant tissues (about 10-50 mg) were electrophoresed in a 1.0\% agarose gel in TBE buffer and then transferred to a sheet of nylon membrane (Hybond $\mathrm{N}$; Amersham) by using the vacuum blotting method ${ }^{14)}$. The membranes were hybridized with peroxidase-labeled DNA probes. Hybridization was performed by using the Amersham ECL gene detection system. After the hybridization, the membrane was washed under highly stringent conditions as described elsewhere ${ }^{14)}$.

Dot hybridization. DNA extracted from approximately equal amounts $(1.0 \mathrm{mg})$ of phytoplasma-infected or healthy plant tissues was denatured and blotted onto nylon membranes (Hybond $\mathrm{N}^{+}$; Amersham). The membranes were hybridized with peroxidase-labeled DNA probes. After the hybridization, the membrane was washed under highly stringent conditions ${ }^{14)}$.

Inverse PCR. DNA fragments of extrachromosomal DNA of SCWL phytoplasma were amplified from DNA of SCWL-infected sugarcane by an inverse PCR procedure. After the sequencing of both ends of the cloned S 1 fragment by a standard method ${ }^{22)}$ using an automatic DNA sequencer (ABI $373 \mathrm{~A}$ ), primers for PCR were constructed for inverse directions. The primers SWLT 3 KA 2: 5'ATGATGATGAACAAGCCGAA 3' and SWLT $7 \mathrm{KA} 2$ : 5'GTTTGGCCTGTTTCCACAGTG 3' were synthesized with a DNA synthesizer (Millipore Cyclone Plus). The reaction mixtures with a strandard concentration ${ }^{22)}$, were subjected to 25 cycles of $1 \mathrm{~min}$ at $92^{\circ} \mathrm{C}$ and $2 \mathrm{~min}$ at $42^{\circ} \mathrm{C}$, followed by $3 \mathrm{~min}$ at $72^{\circ} \mathrm{C}$.

\section{RESULTS}

\section{Isolation of extrachromosomal DNA of RYD phytoplasma}

RYD-To-DNA was separated from host plant DNA by repeated bisbenzimide- $\mathrm{CsCl}$ equilibrium density gradient centrifugations as described elsewhere ${ }^{13)}$. After the sucrose density gradient centrifugation of the isolated RYD-DNA, fractions were collected and analyzed by the agarose gel electrophoresis (Fig. 1 A). Fractions No. 2 and No. 3 contained major low-molecular-weight DNA (about $4 \mathrm{~kb}$ ) of RYD-To that hybridized with extrachromosomal DNA probe R 72 (Fig. 1C). Highermolecular-weight DNA ( $>23 \mathrm{~kb})$ of RYD-To in fractions No. 4 to No. 7 hybridized with chromosomal DNA probe R 9 (Fig. 1 B). These results indicated that the fractions No. 2 and No. 3 contained extrachromosomal DNA, whereas the fractions No. 4 to No. 7 contained nearly full size or partly degraded chromosomal DNA of RYD-To. 


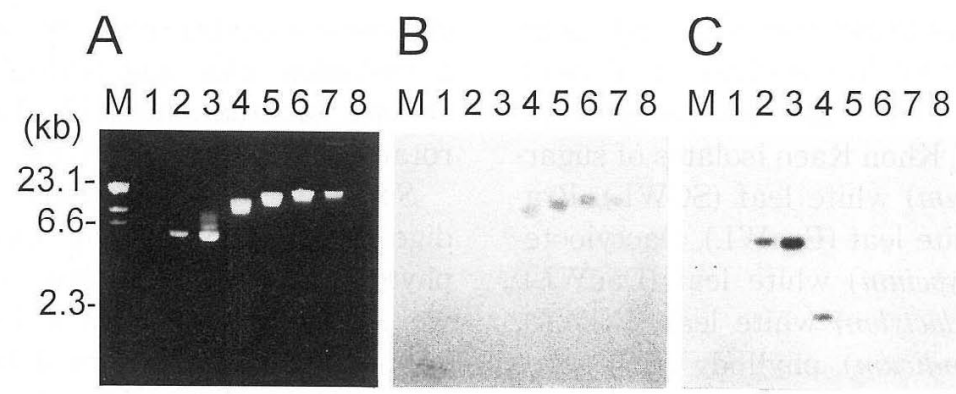

Fig. 1. Agarose gel electrophoresis (A) and Southern blot hybridization with chromosomal DNA probe R 9 (B) or with R 9 and then with extrachromosomal DNA probe R 72 (C) of eight fractions recovered (fractions 1 to 8 from the bottom to the top) after sucrose density gradient centrifugation of DNA from RYD phytoplasma.

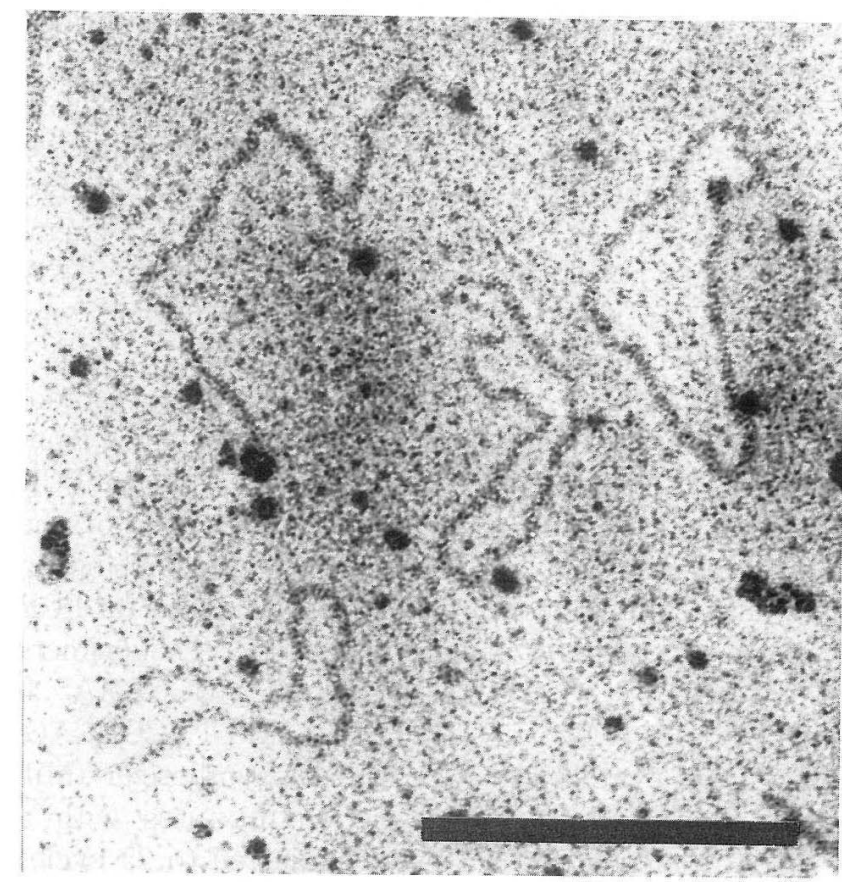

Fig. 2. Electron micrograph of low-molecular-weight DNA molecules of RYD phytoplasma. Bar is $500 \mathrm{~nm}$.

\section{Electron microscopy of extrachromosomal DNA of $R Y D$ phytoplasma}

Under an electron microscope, DNA appeared as circular or linear strands (Fig. 2). The length distribution of circular DNA strands had a major peak at 1173 nm (Fig. $3 \mathrm{~A}$ ). That of linear DNA strands had a wide peak also at $1173 \mathrm{~nm}$. These results indicated that the linear DNAs consisted of a complex of double-nicked extrachromosomal DNAs and degraded ones during extraction and purification processes. By using plasmid Bluescript (Stratagene, 2961 bp) as the standard, extrachromosomal DNA molecule in the peak was estimated as $3.8 \mathrm{~kb}$.

Differentiation of extrachromosomal DNA of RYD phytoplasma

Patterns of HindIII-digests of DNAs from RYD phytoplasma isolates from Japan, Thailand, and the Philippines were compared by Southern hybridization (Fig. 4). There were no differences in the patterns of
A

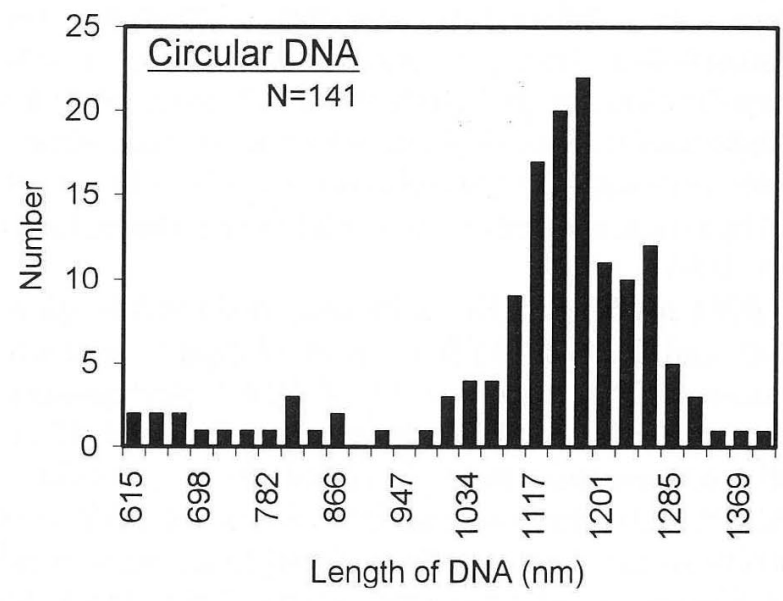

Q

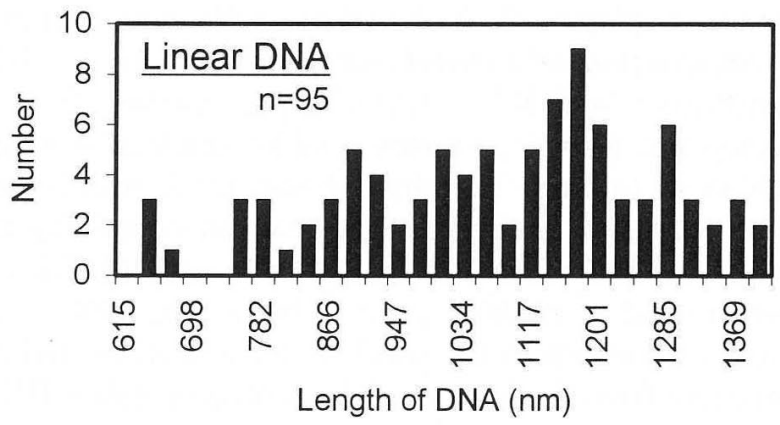

Fig. 3. Length distributions of circular (A) and linear DNA (B) of low-molecular-weight DNA molecules from RYD phytoplasma.

fragmented chromosomal DNAs that hybridized with probes R 9 (Fig. $4 \mathrm{~A}$ ). There were also no recognizable difference in the electrophoretic mobility of DNA bands that hybridized with other chromosomal DNA probes R 12, R 26, or R 30 (data not shown). On the other hand, patterns of fragmented extrachromosomal DNAs or RYD phytoplasma isolates that hybridized with probes R 32 and R 72 were diverse (Fig. 4 B, C). Furthermore, the electrophoretic mobility of each fragment was variable among RYD phytoplasma isolates collected even 
A

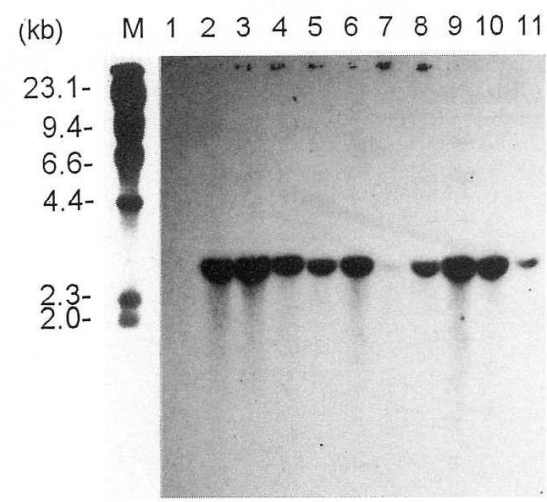

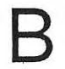

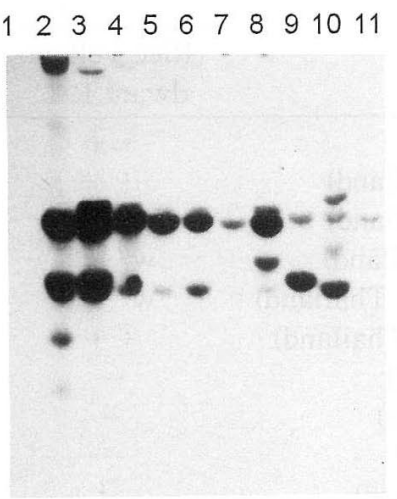

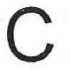

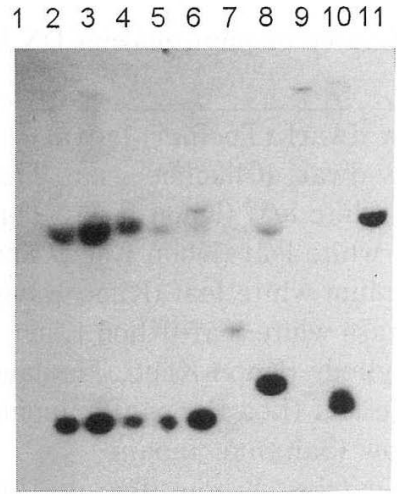

Fig. 4. Southern hybridization of HindIII-digests of DNAs from RYD phytoplasma-infected rice. DNA extracted from healthy rice plants (lane 1), rice plants infected with RYD-To (lane 2), RYD-T-N (lane 3), RYD-T-Ya (lane 4), RYD-T-K (lane 5), RYD-T-U (lane 6), RYD-T-Yu (lane 7), RYD-N (lane 8), RYD-K (lane 9), RYD-Th (lane 10), RYD-Ph (lane 11) phytoplasmas, and lambda/ HindIII digests as molecular weight markers (lane M) were blotted and probed with R 9 (A), R 32 (B), and R 72 (C).

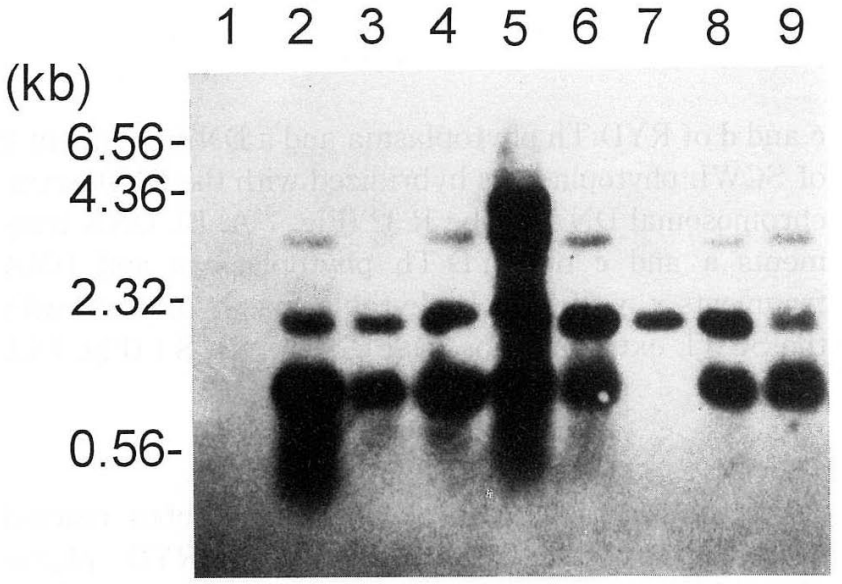

Fig. 5. Variation in extrachromosomal DNA from RYD phytoplasma isolates collected in a field at Yuzukami, Tochigi, Japan. DNA of eight RYD isolates (lanes 2-9) and healthy rice plants (lane 1) was digested with HindIII and probed with extrachromosomal DNA probe R 72 .

from one small paddy field (about $100 \mathrm{~m}^{2}$ ) in Yuzukami, Tochigi, Japan (Fig. 5).

Extrachromosomal DNA of SCWL phytoplasma

Cloned DNA fragments of extrachromosomal DNAs from SCWL phytoplasma were used ${ }^{12)}$. Partial sequencing of the cloned DNA fragment S1 (about $2650 \mathrm{bp}$ ) indicated that the $\mathrm{G}+\mathrm{C}$ content was less than $30 \%$ (data not shown). By utilizing the inverse PCR method, we obtained a DNA fragment of about $130 \mathrm{bp}$ from one end of the S 1 to the other end of the fragment (data not shown), suggesting that the extrachromosomal DNA of SCWL phytoplasma is circular with a size of about 2.7 kb. Variation in extrachromosomal DNA was observed also among SCWL phytoplasma isolates collected in one field (about $100 \mathrm{~m}^{2}$ ) at Khon Kaen, Thailand (Fig. 6).

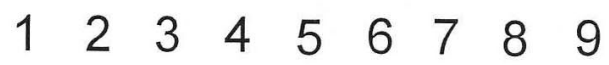

(kb) 4.362.32$0.56-$

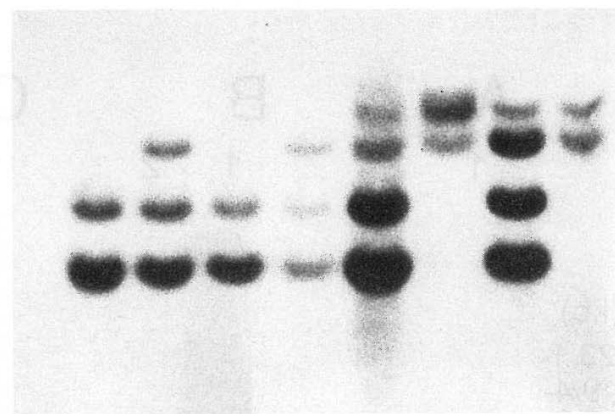

Fig. 6. Variation in extrachromosomal DNA from SCWL phytoplasma isolates collected in a field in Khon Kaen, Thailand. DNA from eight SCWL isolates (lanes 2-9) and healthy sugarcane plants (lane 1) were digested with HindIII \& EcoRI, electrophoresed with $0.7 \%$ agrose gel, blotted onto a nylon membrane, and hybridized with the extrachromosomal DNA probe S1.

\section{Relatedness among extrachromosomal DNAs of phytoplasma}

Results from preferential dot hybridization of extrachromosomal DNA probes of RYD, SCWL, SP, and AY phytoplasmas with DNA preparations from several phytoplasma-infected plants are summarized in Table 1. DNAs from plants infected with RYD-To, RYD-Th, SCWL, BraWL, DacWL, and BGWL phytoplasma, all of which develop chlorosis and/or white leaf symptoms including profused tillering in infected plants ${ }^{12,15)}$, hybridized invariably with SCWL extrachromosomal probe S 1 and showed strong signals. On the other hand, the reaction of SCWL, BraWL, and DacWL to RYD extrachromosomal probe R 32 was inconsistent, while that of RYD-To, RYD-Th, and BGWL was consistently positive. DNA from SP phytoplasma-infected plants 
Table 1. Dot hybridization of extrachromosomal DNA probes of four phytoplasmas with DNA preparations from plants infected with 12 phytoplasmas ${ }^{\text {a) }}$

\begin{tabular}{|c|c|c|c|c|}
\hline \multirow[b]{2}{*}{ Source of phytoplasma DNA } & \multicolumn{4}{|c|}{ DNA probe } \\
\hline & $\begin{array}{c}\text { Rice yellow } \\
\text { dwarf R } 32\end{array}$ & $\begin{array}{c}\text { Sugarcane } \\
\text { white leaf S } 1\end{array}$ & $\begin{array}{l}\text { Sesame phyllody } \\
\text { SP } 49 \text { and } 51\end{array}$ & $\begin{array}{c}\text { Aster yellows } \\
\text { PAY } 45\end{array}$ \\
\hline Rice yellow dwarf (Tochigi, Japan) & ++ & ++ & - & - \\
\hline Rice yellow dwarf (Chachoengsao, Thailand) & ++ & ++ & - & - \\
\hline Sugarcane white leaf (Khon Kaen, Thailand) & $\mathrm{w} /-\mathrm{b})$ & ++ & - & - \\
\hline Brachiaria white leaf (Khon Kaen, Thailand) & $\mathrm{w} /-\mathrm{b})$ & + & - & - \\
\hline Dactyloctenium white leaf (Khon Kaen, Thailand) & $\mathrm{w} /-\mathrm{b})$ & + & - & - \\
\hline Bermudagrass white leaf (Khon Kaen, Thailand) & ++ & ++ & - & - \\
\hline Sesame phyllody (Khon Kaen, Thailand) & - & - & ++ & - \\
\hline Rice orange leaf (Los Banos, Philippines) & - & - & - & ++ \\
\hline Onion yellow (Saitama, Japan) & - & - & - & ++ \\
\hline Paulownia witches' broom (Ibaraki, Japan) & - & - & - & ++ \\
\hline Aster yellows (California, USA) & - & - & - & + \\
\hline Gentian witches' broom (Fukushima, Japan) & - & - & - & - \\
\hline
\end{tabular}

a) DNAs from several phytoplasma-infected plants were blotted onto nylon membranes and probed with extrachromosomal DNA probes of rice yellow dwarf, sugarcane white leaf, sesame phyllody, and aster yellows phytoplasmas. ++ , strong hybridization signal; + , moderate hybridization signal; w, weak hybridization signal; -, negative hybridization signal.

b) Some specimens hybridized weakly with probe $\mathrm{R} 32$.

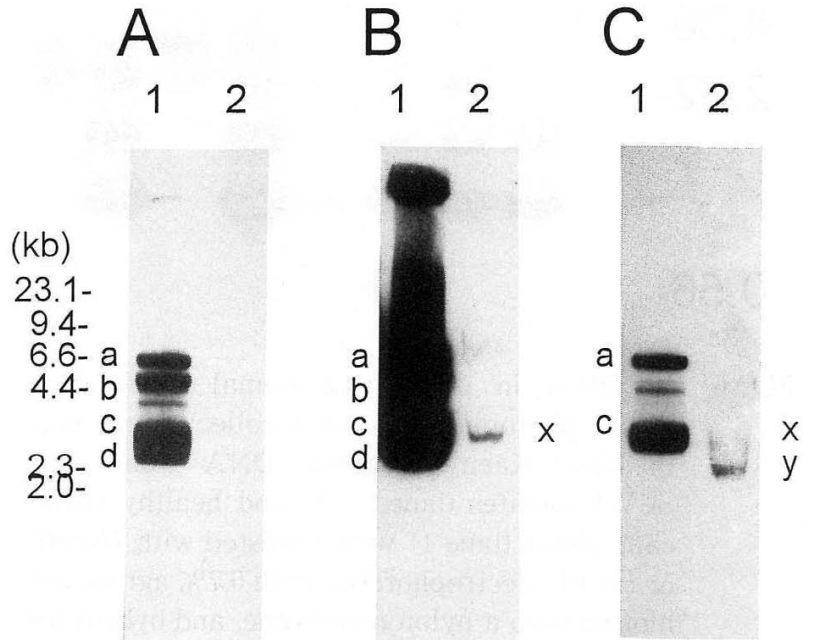

Fig. 7. Southern hybridization of undigested DNA from plants infected with RYD or SCWL phytoplasmas using extrachromosomal DNA probes. DNAs extracted from rice infected with RYD. Th (lane 1) and sugarcane infected with SCWL (lane 2) were blotted, and probed with R 32 (A and $\mathrm{B}$ ), and $\mathrm{S} 1$ (C). Exposure time was $10 \mathrm{~min}$ for plates $\mathrm{A}$ and $\mathrm{C}$, and $1 \mathrm{hr}$ for plate $\mathrm{B}$.

hybridized with the DNA probes SP 49 and SP 51 derived from SP extrachromosomal DNAs. DNA of ROL, OY, PWB, and AY phytoplasma-infected plants hybridized with DNA probe PAY 45 derived from plasmid of AY phytoplasma. None of the extrachromosomal DNA probes used hybridized with DNA of GWB phytoplasmainfected plants. In Southern hybridization with extrachromosomal DNAs of undigested DNA of RYD-Th and SCWL phytoplasma-infected plant, DNA fragments $\mathbf{a}, \mathbf{b}$, $\mathbf{c}$ and $\mathbf{d}$ of RYD-Th phytoplasma and a DNA fragment $\mathbf{x}$ of SCWL phytoplasmas hybridized with the RYD extrachromosomal DNA probe R 32 (Fig. 7 A, B). DNA fragments $\mathbf{a}$ and $\mathbf{c}$ of RYD-Th phytoplasmas and DNA fragments $\mathbf{x}, \mathbf{y}$ of SCWL phytoplasmas hybridized with the SCWL extrachromosomal DNA probe S 1 (Fig. 7 C).

\section{DISCUSSION}

We showed that some cloned DNA probes reacted with low-molecular-weight DNAs of RYD phytoplasma $^{13,14)}$, and cloned extrachromosomal DNA fragments hybridized strongly with the covalently closed circular DNA fraction of RYD phytoplasma obtained by EtBr-CsCl gradient centrifugation ${ }^{14}$. Extrachromosomal DNA was found in a phytoplasma associated with a SCWL isolate in Thailand ${ }^{6,12)}$. Cloned fragments of the isolate hybridized not only with SCWL isolates but also with other phytoplasmas associated with white leaf/ chlorosis symptoms of gramineous plants including RYD phytoplasma ${ }^{12}$. Klingkorn and Seemüller reported that the extrachromosomal DNA of SCWL phytoplasma shows a closed circular form based on two-dimensional electrophoresis ${ }^{6}$. In this report, extrachromosomal DNA of RYD-To phytoplasma was circular and was about $3.8 \mathrm{~kb}$ in size, indicating that the extrachromosomal DNA of RYD phytoplasmas may be a plasmid. On the other hand, inverse PCR confirmed that the extrachromosomal DNA of the SCWL phytoplasma was also circular and about $2.7 \mathrm{~kb}$ in size. Dot hybridization indicated that the extrachromosomal DNAs of RYD, SCWL, and other phytoplasmas associated with white leaf diseases of gramineous plants were related to each other, and different from extrachromosomal DNAs of 
phytoplasmas associated with other types of symptoms. ROL, OY, and PWB phytoplasmas in Asia have extrachromosomal DNAs which were related to that of AY phytoplasma in USA, but the extrachromosomal DNA of the SP phytoplasma is different from all of the others. Extrachromosomal DNAs of GWB phytoplasma is not known. These results are in agreement with the available information on the genetic and phylogenetic relationships among phytoplasmas ${ }^{16,17)}$. Sequence analyses for the coding assignment of extrachromosomal DNAs of RYD and SCWL phytoplasmas are under way.

Our previous studies showed that undigestedextrachromosomal DNAs of RYD phytoplasmas varied in their electrophoretic behavior ${ }^{14)}$. In the study, HindIII-digests of extrachromosomal DNAs of RYD phytoplasma that hybridized with probes R 32 and R 72 showed polymorphism in their electrophoretic behavior, whereas chromosomal DNA of RYD phytoplasma did not show any variation among isolates tested. Furthermore, the hybridization pattern of fragmented extrachromosomal DNAs showed polymorphism among RYD phytoplasma isolates collected even in a small rice field. Extrachromosomal DNAs of SCWL phytoplasma were also polymorphic among isolates collected from a single field. These results indicated that extrachromosomal DNAs of phytoplasma have a wide variation. It is known that viral genomes, such as the smallest fragment of rice dwarf phytoreovirus genome and satellite RNA of cucumber mosaic cucumovirus, collected in a small field are polymorphic ${ }^{1,11)}$. Small molecules associated with viruses and microorganisms, including phytoplasmas, may multiply rapidly and accumulate various sequences as far as they remain functional.

Although the role of extrachromosomal DNAs of RYD and SCWL phytoplasmas is unknown, the DNA may, however, be involved in some important biological functions. All the phytoplasma isolates collected from Japan, Thailand, and the Philippines harbor extrachromosomal DNAs with high sequence homology to each other. These molecules may play an important role in the pathogenesis, as in case of some plant and animal pathogenic bacteria ${ }^{20)}$. Denes and Sinha ${ }^{5)}$ suggested that extrachromosomal DNA of clover phyllody phytoplasma played a certain role in its transmission by insect vectors. Further studies are needed to clarify the function of the extrachromosomal DNAs associated with RYD and SCWL phytoplasmas.

The authors thank Dr. N. Murata, JICA, Pakistan for his valuable suggestions. The authors thank Dr. B.C. Kirkpatrick, University of California, Davis, California, USA, for the supply of DNA probes as well as for his useful suggestions. The authors thank Mr. S. Iwanami of National Institute of Agrobiological Resources, Tsukuba, Japan, and Mr. S. Kato, formerly at National Agriculture Research Center, Tsukuba, Japan for collecting and maintaining the disease samples. This work owes much to collaborative work with Dr. P. Sirithorn, Dr. P. Wongkaew, and Mr. W. Chaleeprom,
Khon Kaen University, Khon Kaen, Thailand, Dr. M. Putta and Dr. S. Disthaporn, Department of Agriculture, Bangkok, Thailand in a JIRCAS-KKU/DOA cooperative project. Assistance extended by Dr. H. Koganezawa, Mr. P.Q. Cabauatan, and Mrs. J. Miranda of IRRI, Los Banos, Philippines through IRRI-Japan Shuttle Research Project; 1991-1993 is also appreciated.

\section{Literature cited}

1. Aranda, M.A., Fraile, A. and Fernando-Garcia-Arenal, (1993). Genetic variability and evolution of the satellite RNA of cucumber mosaic virus during natural epidemics. J. Virol. 67 : 5896-5901.

2. Davis, M.J., Tsai, J.H., Cox, R.L., McDaniel, L.L. and Harrison, N.A. (1988). Cloning of chromosomal and extrachromosomal DNA of the mycoplasmalike organism that causes maize bushy stunt disease. Mol. PlantMicrobe Interact. 1: 295-302.

3. Davis, R.E., Lee, I.-M., Douglas, S.M. and Dally, E.L. (1990). Molecular cloning and detection of chromosomal and extrachromosomal DNA of the mycoplasmalike organism associated with little leaf disease in periwinkle (Catharanthus roseus). Phytopathology $80: 789-793$.

4. Denes, A.S. and Sinha, R.C. (1991). Extrachromosomal DNA elements of plant pathogenic mycoplasmalike organisms. Can. J. Plant Pathol. 13 : 26-32.

5. Denes, A.S. and Sinha, R.C. (1992). Alteration of clover phyllody mycoplasma DNA after in vitro culturing of phyllody-diseased clover. Can. J. Plant Pathol. 14 : 189196.

6. Klinkong, S. and Seemüller, E. (1993). Detection and differentiation of the mycoplasmalike organism associated with sugarcane white leaf disease using cloned extrachromosomal DNA probe. Kasetsart J. 27 : 98-103.

7. Kuske, C.R. and Kirkpatrick, B.C. (1990). Identification and characterization of plasmids from the western aster yellows mycoplasmalike organism. J. Bacteriol. $172: 1628-1633$.

8. Kuske, C.R., Kirkpatrick, B.C., Davis, M.J. and Seemüller, E. (1991). DNA hybridization between western aster yellows mycoplasmalike organism plasmid and extrachromosomal DNA from other plant pathogenic mycoplasmalike organisms. Mol. Plant-Microbe Interact. $4: 75-80$.

9. Lee, I.-M. and Davis, R.E. (1988). Detection and investigation of genetic relatedness among aster yellows and other mycoplasmalike organisms by using cloned DNA and RNA probes. Mol. Plant-Microbe Interact. 1 : 303310 .

10. McCoy, R.E., Caudwell, A., Chang, C.J., Chen, T.A., Chiykowski, L.N., Cousin, M.T., Dale, J.L., De Leeuw, G.T.N., Golino, D.A., Hackett, K.J., Kirkpatrick, B.C., Marwitz, R., Petzold, H., Sinha, R.C., Sugiura, M., Whitcomb, R.F., Yang, I.L., Zhu, B.M. and Seemüller, E. (1989). In The Mycoplasmas, Vol. 5 (Whitcomb, R.F. and Tully, J.G. eds.), Academic Press, New York, pp. 545-640.

11. Murao, K., Suda, N., Uyeda, I., Isogai, M., Suga, H., Yamada, N., Kimura, I. and Shikata, E. (1994). Genetic heterogeneity of rice dwarf phytoreovirus field isolates 
and nucleotide sequences of variants of genome segment 12. J. Gen. Virol. 75 : 1843-1848.

12. Nakashima, K., Chaleeprom, W., Wongkaew, P. and Sirithorn, P. (1994). Detection of mycoplasma-like organism associated with white leaf disease of sugarcane in Thailand using DNA probes. JIRCAS J. 1 : 5767.

13. Nakashima, K., Kato, S., Iwanami, S. and Murata, N. (1991). Cloning and detection of chromosomal and extrachromosomal DNA from mycoplasmalike organisms that cause yellow dwarf disease of rice. Appl. Environ. Microbiol. 57 : 3570-3575.

14. Nakashima, K., Kato, S., Iwanami, S. and Murata, N. (1993). DNA probes reveal relatedness of rice yellow dwarf mycoplasmalike organisms (MLOs) and distinguish them from other MLOs. Appl. Environ. Microbiol. $59: 1206-1212$.

15. Nakashima, K. and Murata, N. (1993). Destructive plant diseases caused by mycoplasma-like organisms in Asia. Outlook Agric. 22 : 53-58.

16. Namba, S., Kato, S., Iwanami, S., Oyaizu, H., Shiozawa, H. and Tsuchizaki, T. (1993). Detection and differentiation of plant-pathogenic mycoplasmalike organisms using polymerase chain reaction. Phytopathology $83:$ 786-791.

17. Namba, S., Oyaizu, H., Kato, S., Iwanami, S. and Tsuchizaki, T. (1993). Phylogenetic diversity of phytopathogenic mycoplasma-like organisms. Int. J. Syst. Bacteriol. $43: 461-467$.

18. Neimark, H. and Kirkpatrick, B.C. (1993). Isolation and characterization of full-length chromosomes for non-culturable plant-pathogenic mycoplasmalike organisms. Mol. Microbiol. 7 : 21-28.

19. Ou, S.H. (1985). Rice Diseases, 2 nd ed., Commonwealth Mycological Institute, Kew, pp. 1-60.

20. Panopolous, N. and Peet, R.C. (1985). The molecular genetics of plant pathogenic bacteria and their plasmids. Annu. Rev. Phytopathol. 23 : 381-419.
21. Rishi, N. and Chen, C.T. (1989). In Diseases of Sugarcane (Ricaud, B.C. and Egan, B.T. eds.), Elsevier Science Publisher, Amsterdam, pp. 289-300.

22. Sambrook, J., Maniatis, T.I. and Fritsch, E.F. (1989). Molecular Cloning : A Laboratory Manual, 2nd ed., Cold Spring Harbor Laboratory, Cold Spring Harbor, New York.

23. Schneider, B., Maurer, R., Saillard, C., Kirkpatrick, B.C. and Seemuiller, E. (1992). Occurrence and relatedness of extrachromosomal DNAs in plant pathogenic mycoplasmalike organisms. Mol. Plant-Microbe Interact. 5 : 489-495.

\section{和 文 摘 要}

中島一雄・林 隆治：イネ黄萎病およびサトウキビ白葉病フ アイトプラズマの染色体外 DNA

イネ黄萎病(RYD)ファイトプラズマとサトウキビ白葉病 (SCWL)ファイトプラズマは, 染色体外 DNA を持つことが明ら かになっている。ショ糖密度勾配遠心により，RYDファイトプ ラズマの染色体外 DNA プローブとハイブリダイズする RYD ファイトプラズマ低分子 DNA を分離した。得られたDNAを， 電子顕微鏡を用いて観察することにより, RYD ファイトプラズ マの染色体外 DNA は, 長さが約 $3.8 \mathrm{~kb}$ の環状および線状の DNA から成ることが示された。インバース PCR 法により， SCWL ファイトプラズマの染色体外 DNA は，植物体内で環状 の形態をとることが示され, 長さは約 $2.7 \mathrm{~kb}$ と推定された。 RYD ファイトプラズマの染色体外 DNA の HindIII 分解物と SCWL ファイトプラズマの染色体外 DNA の HindIII-Eco RI 分解物は，1枚のフィールドから採集した株の間でも多型を示 した。ハイブリダイゼーション実験により，RYD ファイトプラ ズマの染色体外 DNA と SCWL ファイトプラズマの染色体外 DNA の間で, 塩基配列の相同性は極めて高いが，それらとゴマ フィロディーファイトプラズマやアスターイエローズタイプの ファイトプラズマの染色体外 DNA との相同性は低いことが示 された。 